denied the accusation that science is responsible for the horrors of war; dismissed the proposal that scientific workers should refuse to do war work as impracticable; urged them to join with the general public in order to take the necessary political action to stop the use of science for purposes of destruction, and suggested finally that the most suitable form of action would be the setting up of an international police force under the auspices of the League of Nations. Air Commodore Charlton showed how one of the principal technical achievements of our age, the aeroplane, has brought war to our doorstep, and has made the world population centres, such as Londan, the principal military objective in a future war. $\mathrm{He}$ presented quantitative evidence of the inadequacy of all known methods of defence, and urged scientific workers to devise something that would render the use of bombers impossible. In the subsequent discussion, attention was directed to the alternative policies advocated for avoiding war. The general consensus of opinion seemed to be in favour of some system of genuine collective security, and rejected both the isolationist and the pacifist solutions. J. D. Bernal reported the principal recommendations of the Science Section of the International Peace Conference held in Brussels last September. These included the proposal that scientific workers should apply scientific method to the study of war in all its aspects, to investigate the causes of war from the point of view of social and biological science, and to expose pseudo-scientific theories justifying war and racial superiority. It was finally proposed that a national commission representing all branches of science be set up to co-ordinate this work. These recommendations met with the warm support of the meeting.

\section{Social Mission of Science}

TrE "Social Mission of Science", which formed the subject of a leading article in NATURE of October 24, has no more important objective, according to Prof. John Dewey, the veteran philosopher of Columbia University, than to elucidate the relation between authority and freedom. In his address at the Harvard Tercentenary Conference of Arts and Sciences on September 4 on "Authority and Resistance to Social Change" (School and Society, October 10), he exposed two fallacies underlying much of the philosophy that has gone by the name of liberalism, namely, that authority and freedom have separate and independent spheres of activity and no form of authority is justifiable that is not the product of, and sanctioned by, the conscious wants, efforts and satisfactions of individuals in their private capacity. While decrying the principle of authority, this philosophy, in fact, erected the wants and endeavours of private individuals seeking personal gain to the place of supreme authority in social life. Its failure to produce the conditions of a generally shared individual freedom is largely responsible for the recrudescence of the principle of authority in its most extreme and primitive form-the rise of dictatorships.
No collective planned economy, Prof. Dewey said, will succeed without some hitherto untried means for bringing into life an organic co-ordination of authority and freedom. It is here that science may help. It is suggested that the working of co-operative intelligence as displayed in science may serve as a working model of the union of freedom and authority. Here is seen individual freedom that is both supported by collective organized authority and, in turn, changes and is encouraged to change and develop by its own operation the authority upon which it depends. The extension to the wider field of human relations of the method of control by organized intelligence operating through the release of individual powers and capabilities presents enormous difficulties, but it is, Dewey holds, the only means whereby humanity can be rescued from "that futile and destructive oscillation between authoritative power and unregulated individual freedom to which we may justly attribute most of the sorrows and defeats of the past".

\section{The Permanent International Studies Conference}

THE report on the work of the Intellectual Co-operation Organisation, subrnitted by the Sixth Committee to the Assembly of the League of Nations, refers to the expansion of the Permanent International Studies Conference, which is now engaged in an objective and scientific study of foreign policy. This is an autonomous body which is able to pursue its work in the complete independence proper to scientific research. The most recent subjects dealt with by the Conference are State intervention in economic life, the possibility and conditions of an organization of collective security, and peaceful methods of change as applied to particular problems. For 1936 and 1937, the subjects chosen include the procedures for the peaceful settlement of disputes which have been applied in particular cases, over-population, colonies, migration and distribution of raw materials. In the field of education, an important result of the year's work of the Committee has been the publication by the Paris Institute of a first volume dealing with the organization of higher education and research in several European and American countries, while the Committee's efforts in the teaching of history are bearing fruit in the revision of text-books.

SPECIAL interest is attached to the attention which the International Committee is now giving to the question of unemployment among intellectual workers. While this question cannot be separated from the problem of unemployment as a whole, and the remedies to be recommended are chiefly national in character, international action may be of great value, particularly in the nature of co-operation between university information bureaux. Closer relations are being established between the Intellectual Co-operation Organisation and the International Council of Scientific Unions, and a permanent scientific committee is being set up as a result of the meeting of an expert committee to develop the Organisation's work in this field, and conversations on scientific 
subjects contemplated include the future of scientific research and of science in modern societies. In this field also the Institute of Intellectual Co-operation and the International Labour Office have undertaken an inquiry into the social consequences of progress in mechanization, and its effects on man and the circumstances in which he lives. Discussions on the main international systems governing authors' rights have led the Committee to conclude that amalgamation of the Berne Convention and the PanAmerican Convention of Havana is not possible, and a new convention is being prepared with the object of reconciling the principles common to these Conventions and capable of forming the basis of a universal system of authors' rights.

\section{Indian Science Abstracts}

THE immense volume of original work now published necessitates a very complete system of abstracts, and the requirements of the individual sciences are now well served in this respect. Rarely, however, is an attempt made to abstract separately the scientific publications of any country, so that it is not possible to estimate its direct contributions to knowledge. Prior to the Great War, the now defunct Board of Scientific Advice published annually a résumé of the principal Indian scientific memoirs, and now, after the lapse of many years, the National Institute of Sciences in India has undertaken the much more difficult task of compiling an annual bibliography of science in India. This comprises not only the titles of all papers published by authors resident in India and of Indians working abroad, but also of papers dealing with problems specifically related to India. In the majority of cases, not only is the title of the paper given, but it is also followed by a brief, but adequate, abstract. To those who look upon India as a backward country this publica. tion will come as a revelation, not merely from the volume of the work produced but also by the high standard to which much of it attains. In a country so predominantly agricultural it is gratifying to find that so much attention is being paid to biological subjects ; nearly one half of the abstracts come under the heads of botany, zoology and physiology, the latter including veterinary and medical subjects. As the general editor points out in his introduction, the present division of subjects, which is under nine main heads, is purely tentative and may require revision in the light of experience.

Future historians of science are sure to find this publication invaluable, but we would suggest that the addition of an author index would facilitate reference. To the general editor, Dr. Baini Prashad. and to his associate editors, we would offer our congratulations, and we trust that the favourable reception which is sure to be accorded to these abstracts will encourage them to continue the issue of the bibliography. Further evidence of the great attention now being devoted to research in India is found also in the publication by the Inter-University Board, India, of a bibliography of the theses accepted for higher degrees in arts and science by the univer. sities during the years 1930-35. By their system of external examiners, the Indian universities ensure that their higher degrees shall equal those of the Western universities, and this bibliography shows how active these young universities are as centres for the advancement of knowledge. It will go far to dispel the idea that they are merely examining bodies.

\section{Post Office Tests of Inoculation against Colds}

THE common catarrhal cold is responsible for much sickness disability, and preventive vaccines containing a mixture of the predominant microbes present in the secretions have been employed, the microbes being bacteria such as $M$. catarrhalis, B. hofmanni, Friedlander's bacillus, Pneumococcus, Staphylococcus and Streptococcus. Trials of such a vaccine in the past, some of them on a large scale, have been disappointing, occasionally seeming to be useful in individual cases, but not significantly so in any large groups. A further test by the Chief Medical Officer of the Post Office during the last three years upon a large scale has, it is announced, similarly been disappointing. Volunteers were invited from large towns, and some hundreds of them were inoculated in the autumn of the three years 1933-35, and their sickness rates over periods antedating the inoculations and during the treatment were compared. Comparisons were also made with large control groups in each place of uninoculated workers. About ten per cent of the volunteers-less than half the original number-who persisted throughout the three years of the experiment showed some improvement, but taken as a whole the results were not encouraging, for there was little reduction of sickness among the whole group compared with the control groups or with their previous record. The use of anti-catarrhal vaccine as a large-scale routine measure in the future is, therefore, not considered justifiable. The negative character of the results of this experiment is not unexpected, as the common cold is now regarded as being a virus disease, the bacterial organisms associated with it being of the nature of secondary invaders.

\section{Civilization since James Watt}

AT a dinner given by the Franklin Institute on January 21, 1936, to celebrate the two hundredth anniversary of the birth of James Watt, J. P. Boyd gave a thoughtful address, a résumé of which appears in the Journal of the Franklin Institute for September. He pointed out that while James Watt was still an infant, Saint-Pièrre had suggested that the attain. ment of knowledge and the subjugation of the material world to the requirements of human welfare would lead to a continual improvement in the lot of mankind. But the logic of academicians and the pamphleteering of philosophers could not compare in effectiveness with the work initiated by James Watt. The steam engine meant freedom from the limitations of time and space. England in 1750 contained seven million inhabitants, and was over.

\section{(Continued on p. 925.)}

